DOI 10.37882/2500-3682.2021.06.08

\title{
КЛАССИЧЕСКОЕ ЕВРАЗИЙСТВО И СОВРЕМЕННОСТЬ
}

\section{CLASSICAL EURASIANISM AND MODERNITY}

\section{Kocharsky}

Summary: The article reveals the essence of classical Eurasianism in the 1920-1930s. The article emphasizes the relevance of the Eurasian concept on the example of the formation of interstate organizations and the modern development of the concept of classical Eurasianism in the form of Neoeurasianism. The presented article is devoted to study the modern understanding of classical Eurasianism, in the works of leading scientists in this area. The author concluded that the political-philosophical classical concept of Eurasianism has undergone dramatic changes, for example, in the works of A.G. Dugin. But there are exceptions, as A.S. Panarin became one of the successors of the authentic ideas of Eurasianism.

Keywords: Eurasianism, neourasianism, orientalism, geopolitics, Russian emigration.
Кочарский Лев Савельевич

Аспирант, Сочинский государственный университет; м.н.С., ФГБУН «Федеральный исследовательский чентр «Субтропический научный чентр Российской академии наук», г. Сочи lum.mas@yandex.ru

Аннотация: Статья раскрывает содержание классического евразийства 19201930-х годов. В статье подчеркивается актуальность евразийской концепции на примере образования межгосударственных организаций и современного развития концепта классического евразийства в форме неоевразийства. Представленная статья посвящена исследованию современного понимания классического евразийства, в трудах ведущих отечественных и зарубежных ученых в данной сфере. Автор пришел к выводам, что политико-философская концепция классического евразийства в настоящее время претерпела серьезные изменения, например, в работах А.Г. Дугина. Но существуют и исключения, так А.С. Панарин стал одним из продолжателей аутентичных идей евразийства.

Ключевые слова: евразийство, неоевразийство, ориентализм, геополитика, русское зарубежье.

сертаций по данной теме растет из года в год. Необходимо отметить заинтересованность как отечественных А.Г. Дугин, А.С. Панарин, так и западных исследователей, таких как 3. М.Бассин, М. Ларуэль в изучении России как особого региона, находящимся между Европой и Азией $[1,2,3,4]$. В научных кругах идут дискуссии насчет генезиса евразийства, т.е. в науке нет единого мнения на данную политико-философскую концепцию. Все это указывает на значимость изучения данной политикофилософской концепции, но для изучения современных концепций неоевразийства, следует изучить историю и развитие аутентичной идеи.

В данной работе будут использованы такие частнонаучные и междисциплинарные методы как: метод исторических параллелей и метод сравнительного анализа. Метод исторических параллелей, будет применен, для обобщения опыта подлинных идей евразийства с современным опытом неоевразийства. Сравнительный анализ, как метод будет выступать для выявления современных тенденций и специфики политико-философской концепции исследуемой в работе.

«Принадлежит ли в этом смысле Россия к Европе? К радости или же печали, к беде или благой судьбе - нет не принадлежит. Россия не кормилась ни одним из сущностных корней, которым кормилась Европа, принимая вредные и полезные соки из грунта ею же пораженного Древнего мира, не всасывала своими отростками, пищи той что зиждилась из глубины германского Духа. Наша страна не входила в состав империи, где правил Карл Ве- 
ликий, которая выступает общим стволом, при расчленении которого, появилось раскидистое европейское древо, не значилась частью теократической федерациии, которая пришла на замену монархии, не была единым феодально-аристократическим организмом, которая (при Карле Великом, так и в эпоху рыцарства), отсутствовало почти все национальное и являлось общеевропейским учреждением в полном смысле этого слова.

Погодя, когда настала новая эпоха и иной порядок вещей, Отечество так же не участвовало, в противостоянии с феодальным гнетом, итогом которого стала та форма гражданской свободы, которую сейчас имеет Европа; не противостояла и с ложными христианскими учениями (творения тьмы, гордости и лжи, называющим себя католичество) и нет необходимости в этаком виде религиозной дозволенности как протестантство. Не было в России воспитательного воздействия и обременения именуемого схоластикой и не, развивала ту свободу мысли, которая создала современную науку, не жила идеалами, которые выражались в германо-романском типе искусства.

Иными словами, наша страна не причастна, ни к европейскому злу (Крестовые походы, междоусобные войны и т.д.) ни к европейскому добру (Великие географические открытия, развитие науки и техники и тд.) Как же она может быть Европой? Ни благая скромность, ни истинная гордость не дозволяют России считаться Европой» [5, с.5-6].

Евразийство - философско-политическая концепция, появившаяся в среде русской эмиграции в 20-е-30-е годы прошлого столетия. Она возникла, как ответ на философско-политическую тенденцию такую, как европоцентризм. Основная идея данного социально-философского учения, заключалась в самобытности России, как цивилизации [6, с.43]. Условно можно разделить концепцию евразийства на 3 этапа: классический, советский и неоевразийство.

Классический этап был обусловлен эмиграцией интеллигенции в 20-30x годах XX века. Представителями данного периода являются: Н.С. Трубецкой, основатель евразийского концепта, лингвист и филолог, Г.В. Флоровский - патролог, историк и богослов, П.П. Сувчинский музыкальный и литературный критик; Г.В. Вернадский геополитик и историк и другие. Представители первой волны евразийства (1921-1929 гг.), в своей концепции и трудах, использовали этнографический, исторический, географический и политико-правовой опыт, изучая проблематику развития отношений Запада и Востока.

Все это привело к созданию новых социально-философских взглядов на счет применения и развития этой идеологии в России. Исходя из их позиций, Россия яв- ляется уникальной цивилизацией, которая во многих аспектах (культуры, истории, географии, менталитета и т.д.) не относится ни к азиатской, ни к европейской цивилизации [7, с.205-207]. «Евразийский кружок» привлек к себе внимание русской эмиграции. После выдвижения своих идей и взглядов представителями классического евразийства, на место России в социально-культурном развитии, проводились открытые заседания «евразийского кружка». Следствием этого стали острые споры вокруг этой социально-философской концепции, дошедшие до заграничных газет и журналов.

В современной науке мнения насчет интерпретации классического евразийства в частности, так и развития неоевразийства в целом весьма различны. Отечественный философ А.Г. Дугин отмечает: «Идея о стратегическом треугольнике Москва - Пекин - Дели и идея Путина- Ельцина о «многополярном мире» есть не что иное, как ничто иное как концепт евразийства на межгосударственном уровне» $[9$, с.5].

Однако французский историк М. Ларюэлль, справедливо отмечает «Классическое евразийство, первоначально являлось идеей «третьего пути», которая существовала как в левом, так и в правом вариантах, его адаптация современными неоевразийцами, к примеру Дугиным в крайне правом направлении является отрицанием глубины социально-философской концепции и интеллектуального богатства евразийства. В том числе, все это является присвоением достояния его отцов-основателей: ни один из них не стал сторонником нацизма во время Второй мировой войны» [8, с.6-7]. В научном сообществе, «неоевразийство Дугина», подвергается критике за перестройку самой идеи евразийства в угоду политического заказа. На данном примере четко прослеживается тенденция искажения основ политико-философской концепции.

С другой стороны, можно отметить работы А.С. Панарина [2]. В них ученый опирается на первоисточники русской интеллигенции, пытаясь исключить свой личностный аспект понимания. В этом случае в классическое евразийство «вдыхается новая жизнь» и только лишь обогащается современным опытом, выражаясь в концепции неоевразийства. В этой связи, необходимо отметить точку зрения профессора М. А. Маслина «потенциал неискаженного евразийства, продолженный в классической традиции социально-философской концепции, до сих пор актуален и сохраняет свое значение для применения в практике и теории политического консерватизма» [11, с.30-31].

Классическое евразийство и сейчас сохраняет свою актуальность, потому что данная мировоззренческая установка обобщила ключевые понятия для политологии и философии. Например, продолжая линию Шпен- 
глера и Данилевского евразийцы, в своих трудах выделяли Россию как особую цивилизацию. Основатели евразийства поставили перед собой цель по выработке формулы русского консерватизма - политической идеологии, которая основывалась на географическом положении России, специфике её истории и традиций.

Также одним из ключевых элементов евразийства, выступала православная традиция, которая, отрицая позитивный характер европейской цивилизации, противопоставляла себя христианским направлениям католицизма и протестантизма. Евразийцы агитировали за борьбу с «кошмаром всеобщей европеизации», отмечая, что: «Нам необходимо привыкнуть к мысли, что вся романо-германская культура - является нашим заклятым врагом». Об этом писал основатель политико-философ- ского движения, князь Н.С. Трубецкой в 1921 году [8, 9].

Проанализировав основные точки зрения, направленные на понимание классического евразийства в современной науке, необходимо отметить, что евразийство, выступает как современная постсоветская идеология, которая имеет культурно-исторические истоки и направлена на исключительность и самобытность нашей страны. Следует отметить высокую заинтересованность к данной политико-философской концепции ряда отечественных и зарубежных исследователей, обозначенных в работе. Исходя из этого евразийство, остается актуальным и дает развитие новым политическим концепциям и международным объединениям (СНГ, ОДКБ, Еаэс и тд). Следует так же подчеркнуть современную тенденцию «отхода» евразийского движения от его истоков.

\section{ЛИТЕРАТУРА}

1. Дугин А.Г. Теория многополярного мира. М: Евразийское движение, 2017. 532 с.

2. Панарин А.С. Атлантизм и евразийство: два сценария для России // Россия: опыт национальногосударственной идеологии. М: 1994.325 с.

3. Bassin Mark. Russia between Europe and Asia: The Ideological Construction of Geographical Space. [Электронный ресурс]. - Режим доступа: URL:https://www. cambridge.org/core/journals/slavicreview/article/abs/russia-between-europe-and-asia (дата обращения: 13.03.2021).

4. Marlène Laruelle. Lidéologie eurasiste ou comment penser l'empire. Paris, L'Harmattan. Paris. 2018. 425 p.

5. Данилевский Н.Я. Россия и Европа: Взгляд на культурные и политические отношения Славянского мира к Германо-Романскому. 6-е изд. / СПб: Издательство «Глаголь», 2016.552 с.

6. Философия: Энциклопедический словарь. М.: Гардарики. Под редакцей А.А. Ивина. М: 2018. 632 с.

7. Трубецкой Н.С. История. Культура. Язык. М: 1995.400 с.

8. Исход к Востоку. Предчувствия и свершения. Утверждение евразийцев. София:. 1921.

9. Дугин А.Г. Евразийская платформа. Национальная идея является из чрева истории // Независимая газета. 2000. 25 ноября. 15 с.

10. Laruelle M. Alexander Dugin: A Russian Version of the European Radical Right? // Kennan Institute Occasional Papers. №. 294 (2006). p. 1-26.

11. Маслин М.А., Лупова А.А. Эволюция евразийской идеи // Евразийство: Исследования и публикации / Гл. ред. Ю.В. Мухачев. М.. 2014. с. 249.

(c) Кочарский Лев Савельевич (lum.mas@yandex.ru). 